The act to provide for the protection of the salmon fisheries of Alaska, approved June 9, 1896, was amended in the Senate by the passage of the following section:

Sec. 2. That it shall be unlawful to fish, catch, or kill any salmon of any variety, except with rod or spear, above the tide waters of any of the creeks or rivers of less than 500 feet width in the Territory of Alaska, except only for purposes of propagation, or to lay or set any drift net, set net, trap, pound net, or seine for any purpose across the tide waters of any river or stream for a distance of more than one third of the width of such river, stream, or channel, or lay or set any seine or net within 100 yards of any other net or seine which is being laid or set in said stream or channel, or to take, kill, or fish for salmon in any manner or by any means in any of the waters of the Territory of Alaska, either in the streams or tide waters, except Cook Inlet, Prince William Sound, Bering Sea, and the waters tributary thereto, from midnight on Saturday of each week until midnight of the Sunday following; or to fish for or catch or kill in any manner or by any appliance, except by rod or spear, any salmon in any stream of less than 100 yards in width in the said Territory of Alaska between the hours of 6 o'clock in the evening and 6 o'clock in the morning of the following day of each and every day of the week.

The bill to prohibit aliens from taking fish from the waters of the District of Alaska, passed the Senate.

The House bill authorizing the Secretary of the Interior to lease land in Stanley County, South Dakota, for a buffalo pasture, was reported from the Committee on Public Lands, of the House, and referred to the Committee of the Whole.

\section{THE COMING MEETING OF THE MUSEUMS} ASSOCIATION OF AMERICA.

ON the fifteenth of May, at the American Museum of Natural History, Central Park, New York, a meeting will be held in order to organize 'The Museums Association of America.' Already the administrative heads of almost all of the more important museums, both of art and of natural history, in the United States and Canada have signified their intention, if possible, to be present at this meeting, and many have signified their pur- poses to read papers upon important subjects connected with the work of museums. The trustees of the Botanical Garden in Bronx Park have invited those attending this preliminary meeting to accept their hospitalities during one day's session, and have tendered a luncheon to the association. The committee of arrangements desires all who may be connected with museums in official capacities, or who take an interest in the work of museums, and who may desire to enroll themselves in such an organization, to signify that fact to the undersigned, who will, upon receipt of an intimation of their desire to be enrolled as members of the association, send to them at once the proper papers to be filled out.

It is hoped that this invitation will meet with a general response.

The Carnegie Museum, Pittsburg, Pa.

\section{SOIENTIFIC NOTES AND NEWS.}

A BILL granting permission to Professor Simon Newcomb, U. S. N., to accept the decoration of the order 'Pour le Mérite, für Wissenschaften und Kunste,' tendered by the emperor of Germany, passed the senate on February 8.

M. H. DE Chatelier, professor of chemistry in the Collège de France, has been elected a corresponding member of the Berlin Academy of Sciences.

Emperor Wilhelm has appointed Professor Ernst von Bergmann a member of the upper house of parliament (Herrenhaus) for life. This is the first time that such an honor has been conferred on a member of the medical profession.

DR. W. J. Holland, the director of the Carnegie Museum, has accepted the invitation of the editor of the 'Encyclopedia Britannica,' London, to prepare the article upon Natural History Museums for the twelfth edition of the encyclopedia.

GLASGow UnIVERSITy will confer its doctorate of laws on Robert E. Frasher, F.R.S., superintendent of the admiralty experiment works and member of the admiralty committee on warship designs. 